\title{
Evaluating the use of recycled coal combustion products in constructed wetlands: An ecologic-economic modeling approach
}

\author{
Changwoo Ahn, William J. Mitsch \\ Environmental Science Graduate Program and School of Natural Resources, \\ The Ohio State University
}

\section{Introduction}

Nearly $90 \%$ of the electricity produced in Ohio is generated from coal burning and the state generates about $12 \%$ (11.6 million tons) of all coal combustion products (CCPs) in the United States (American Coal Ash Association Survey, 1997). These products, generated in large quantities, have traditionally been treated as wastes and disposed of in expensive, non-productive landfills. However, the disposal of this enormous volume of waste becomes increasingly difficult as landfill costs increase and landfill space decreases. Flue-Gas-Desulfurization (FGD) by-product, one of the CCPs, is the result of lime scrubbing of sulfur oxides from flue gases of coal-fired electrical generating stations to reduce acid deposition. More than 7.5 million tons of FGD by-product are produced annually in Ohio, making it the largest single-produced material in the state (Wolfe et al., 2000).

Efforts have been made to reuse FGD wastes in such beneficial ways as in highway and civil engineering applications, as waste-storage pond liners, and as an agricultural liming substitute in livestock feeding pads (Wolfe et al., 2000). One potential use of FGD by-product is as a liner for the construction of treatment wetlands. Ahn et al. (2001) tested FGD by-products as liners in constructed wetlands through $1-\mathrm{m}^{2}$ mesocosm experiments over two years. Their results showed not only the possibility of the material as an alternative liner to commonly used commercial clay or bentonite, but also the potential of additional phosphorus retention in the treatment wetlands as a result of the FGD material itself.

There are three potential benefits of recycling FGD by-products as a liner in constructed wetlands to treat nutrients over natural or commercial clay materials. These benefits are:

1) Lower costs for obtaining the recycled FGD by-product for liners as the material is basically free except for handling and hauling costs.

2) Reduction in the volume of a waste product that is otherwise disposed of in landfills.

3) Enhanced phosphorus retention due to the chemical characteristics of the FGD liner material (Ahn et al., 2001).

Dynamic models of phosphorus retention in wetlands have been studied extensively (Kadlec and Hammer, 1988; Mitsch and Reeder, 1991; Kadlec, 1997; Richardson et al., 1997; and Wang and Mitsch, 2000). Some studies have also attempted to interlink ecology model and economic analysis (Baker et al., 1991; Breaux et al., 1995; Grant and Thompson, 1997; Robles-Diaz-de-Leon and Vava-Tudela, 1998; van der Belt et al., 1998; Cardoch et al., 2000). Few studies, however, have been conducted to connect ecological functions of constructed wetlands (e.g., phosphorus retention) with their economic consequences through a combined ecologic-economic modeling approach.

The goal of this study was to develop a dynamic model which simulates phosphorus retention incorporated with economic benefits of recycling FGD waste as a liner in constructed wetlands. This model allows an a priori cost savings calculation of recycling FGD by-product as liners relative to using clay material.

\section{Site description}

\section{Olentangy River Wetland (ORW)}

Two 1 ha experimental wetland basins of the Olentangy River Wetland Research Park (ORWRP) in Columbus, Ohio were constructed on alluvial, old-field soils adjacent to the third-order Olentangy River in 1994 (Mitsch et al., 1998). The wetlands are fed by the Olentangy River. Nairn and Mitsch (2000) and Spieles and Mitsch (2000) described phosphorus and nitrogen retention in these experimental basins in detail.

\section{A Pilot-Scale FGD-Lined Wetland System at the ORWRP}

A medium-scale FGD-lined wetland study is currently underway at the ORWRP. This is a larger scale effort than the mesocosm studies conducted by Ahn et al. (2000) to further investigate the effects of FGD by-product recycled as liners in treatment wetlands. This pilot-scale wetland study, being conducted over the next two years (2001 -2002), is expected to provide essential information before going to full-scale application of FGD by-products in building wetlands.

Four separate pilot wetland basins were constructed $(\approx$ $3 \mathrm{~m} \times 7.8 \mathrm{~m} \times 1.5 \mathrm{~m})$. All basins were placed in parallel. A $0.15 \mathrm{~cm}$ plastic liner and a geo-membrane such as those used in landfill caps were fitted to the four basins and welded appropriately so that the material covered both the wetland basins and the berms in between the basins. A layer of gravel approximately $0.2-0.3 \mathrm{~m}$ deep was then added to the cells to serve as the subsurface strata of these basins. FGD by- 
product was then applied to two of the basins and the berms in between, and compacted by excavating machinery to 0.3 $\mathrm{m}$. Recompacted clay was applied to the other two basins in the same fashion. Approximately $0.3 \mathrm{~m}$ site soil obtained during the excavation was then added to all four basins as a medium for wetland vegetation to grow in. We used the dynamic model we developed in this study to suggest design parameters for this pilot-scale wetland. Hydraulic loading rate $\left(\mathrm{cm} \mathrm{day}^{-1}\right)$ and inflow TP concentration were manipulated in the model to achieve optimal conditions for phosphorus retention in the model simulations.

\section{Licking County Wetland (LCW)}

Licking County Wetland (LCW), located near Kirkersville, Ohio, was constructed in 1995 for the tertiary treatment of municipal wastewater effluent from the Southwest Licking Community Water and Sewer District treatment plant (Mitsch and Metzker, 1996; and Spieles and Mitsch, 2000). The wetland site consists of two 3.2 ha basins built on alluvial, previously farmed soils which discharge water into the South Fork of the Licking River, a second order stream. Secondarily treated wastewater has fed both the Wetland North (LCWN) and the Wetland South (LCWS) since the spring of 1995. Wetland South (LCWS), however, proved to be leaky and did not retain water in 1996. Subsequently, all wastewater was routed to LCWN for the duration of the study. This specific condition of LCWS may provide a good case for testing FGD waste as a liner in the future as our pilot-scale wetland study on the material reveals more information. The model was thus applied to the LCW to simulate its ecologic-economic dynamics when lined with either clay or FGD by-product. The simulations calculated the potential cost savings of recycling FGD by-products as a liner as well as phosphorus retention efficiency in the LCW.

\section{Simulation Methods}

The goal of the ecologic-economic wetland model was to enable prediction of phosphorus retention and estimation of cost saving of building wetlands lined with recycled FGD waste. Hydraulic loading rates and total phosphorus (TP) inflow concentrations over a two year period (1996-1997) from ORW basin 1 (ORW 1) and LCWN were used as input for model calibration and validation to investigate general performance of the model in phosphorus retention. All initial conditions for the model were obtained from ORW 1 through previous studies (e.g., Harter and Mitsch, 1999). Four submodels were developed such as hydrology, macrophyte, phosphorus and economic submodels. Each submodel was linked to the previous submodel(s) and calibrated. A set of nonlinear, ordinary differential equations was used to describe the submodels. The model was integrated using the software STELLA\% V, a high level visual-oriented programming and simulation language for use on Apple
Macintosh $^{\mathrm{TM}}$ computers (Richmond and Peterson, 1997). Fourth-order Runge-Kutta was used as the integration method with a time step of 0.1 week. Simulations were designed to run over a two year period (from 1 January of year 1 to 31 December of year 2) in constructed surface-flow wetlands. Calibration was carried out by adjusting selected parameters in the model to obtain a best fit between model estimations and field data from ORW 1 for TP retention. A stepwise method (Mitsch and Reeder, 1991; and Wang and Mitsch, 2000) was used in this process by first calibrating the hydrology submodel, then macrophyte submodel, phosphorus submodel, and finally economic model. At each step, values of parameters determined during the previous step were not allowed to change from previously calibrated values.

Sensitivity analysis is usually performed during model simulations to find the most important parameters which determines the main state variables of interest (JØrgensen, 1988). Wang and Mitsch (2000) verified that TP inflow concentration and phosphorus sedimentation coefficient (sed k in our model) were the most sensitive parameters explaining TP retention in a dynamic phosphorus model of created wetlands. Therefore, we carried out sensitivity analysis of TP inflow concentration and the sedimentation coefficient (sed $\mathrm{k}$ ) on corresponding changes of TP retention (\%) in our model runs with the LCW. The selected parameters were varied by \pm 2 orders of magnitude for TPinflow concentration and by \pm 10 through $80 \%$ for sed $k$. Sensitivity analysis was also conducted in the economic submodel to investigate the effects of changing inflow phosphorus loading on potential economic benefits of FGD-lined wetlands. Total annualized cost saving estimates were based on a 30-year lifetime and $8 \%$ interest rate following current industry practices. The sensitivity of these assumptions was also investigated. Assumptions were made in developing the ecologiceconomic wetland model, including the following:

1) vegetation uptake of phosphorus is from sediments and not from the water column (Richardson, 1985);

2) phosphorus sedimentation is influenced by plant biomass (Kadlec and Knight, 1996);

3) a slight toxic effect of FGD by-product on early development of macrophyte is expected (Ahn and Mitsch, 2001);

4) enhanced phosphorus retention occurs because of the FGD material (Ahn et al., 2001) and the rate is similar over the first 2-year period of wetland operation;

5 ) the growing season for the model is for mid-temperate regions and begins early April and ends mid September;

6) seepage from the wetland basin is assumed zero with any liner being applied;

7) no matter which material, either FGD by-product or clay, is used as a liner it needs to be hauled to the wetland site from a similar distance. 


\section{Model Description and Calibration}

A conceptual model of the constructed wetland with economic system is shown in Figure 1. Differential equations used for the model are presented in Table 1 and state variables, forcing functions and parameters are summarized in Table 2. The model is described in detail below.

\section{Hydrology Submodel}

The hydrology submodel has only one state variable, water volume $(\mathrm{V})$, which balances a pumped inflow, seepage and a surface outflow from the wetland. The hydraulic inflow loading based on field data collected over the 2-year period (1996-1997) at ORW 1 (Table 3) was used in model calibration. Surface outflows were predicted by regression with wetland volume data for both ORW 1 and LCWN. Seepage to groundwater was included as a function of wetland area. Seepage coefficient (SC) was calibrated based on field estimation of seepage. In simulations of a constructed wetland with any liner being applied, either clay or FGD by-product, seepage was set to zero in the model.

\section{Macrophyte Submodel}

The macrophyte submodel includes two state variables: biomass and detritus. Macrophyte production included only aboveground biomass in this model. A solar efficiency of $2.5 \%$ (e.g., Wang and Mitsch, 2000) was estimated and applied to simulate net primary productivity of macrophytes in the submodel. An estimated $20 \%$ reduction in plant growth was applied as a toxicity effect with a FGD material (Ahn and Mitsch, 2001) only during the first growing season (13-38th week) of the wetland model simulated with a FGD liner. An $0.8 \%$ recovery per week was applied to simulate the mitigation of toxicity effects over that time as the potential toxicity in experiments by Ahn and Mitsch (2001) was observed to lessen, and was negligible in the second year with full-grown plants. The toxicity factor was designed as a conditional sentence with an on/off switch (Table 1). It was also assumed that the dominant vegetation in this system is Schoenoplectus tabernaemontani, the most common species in the constructed wetlands explored in this study ( $\approx 90 \%$ of vegetation cover).

Net primary productivity (NPP) depends on solar energy, length of growing season, and FGD toxicity factor. Frost is a pulse function that occurs on the 41 st week of the year. It signifies the first frost of the season that dispatches the living biomass stand into detritus. One other variable, standing stock, is included in the macrophyte submodel, and is connected to the phosphorus submodel. Standing stock, the sum of biomass and detritus held above the surface of the wetland substrate, is assumed to influence water movement and so positively affects the phosphorus sedimentation rate in the phosphorus submodel whether alive or dead. A similar approach in modeling macrophyte dynamics was used in Baker et al. (1991) and Flanagan et al. (1994). The standing stock serves as a set of 'living weirs' that reduce the velocity of the inflow, thereby enhancing physical sedimentation of phosphorus. Physical sedimentation is the major pathway of phosphorus retention through wetlands (Wang and Mitsch, 2000). The effect of temperature on detritus decay was assumed to follow an exponential function based on Brown and Barnwell (1987).

\section{Phosphorus Submodel}

The phosphorus submodel consists of four phosphorus pools and numerous auxiliary variables and pathways, describing general phosphorus dynamics in constructed wetlands (Table 1). Biomass P, Detritus P, Sediment P, and Water $\mathrm{P}$ are the four main state variables in this submodel (Table 2). Water P, the amount of phosphorus in water, has one inflow (Inload) and four outflows (Outload, Sedimentation, P seepage and FGD effect) (Table 1). Inload is dependent on pumped water inflow $\left(\mathrm{m}^{3} \mathrm{wk}^{-1}\right)$ and phosphorus concentration $\left(\mathrm{g} \mathrm{m}^{-3}\right)$. Outload carries phosphorus out of the system and is also dependent upon amount of phosphorus left in water column, water outflow, and the volume of water in the wetland (Table 1). Sedimentation was the second outflow, thus removing phosphorus into the sediments. Sedimentation is controlled by several factors including amount of phosphorus in water column and the amount of standing stock in the wetland. Sedimentation coefficient (sed k) was obtained through model calibration to find a better fit between observed and simulated percent TP removal. Phosphorus seepage accounted for a certain amount of phosphorus lost from the water column through seepage, but this term is designed to become zero when liners are used in the wetlands due to the assumption of no seepage. FGD effect was included in the model as the fourth outflow of Water P. To simulate the enhanced P removal observed through the experiments by Ahn et al. (2001), approximately 10\% more phosphorus (as mass) was simulated to be removed from the water column in wetlands being built with FGD liners. A potentially negative impact of FGD materials on phosphorus retention, such as decreasing sedimentation by lowered standing stock when FGD toxicity is active, is also included in the model. Most phosphorus used by macrophytes is taken up from sediments (Wang and Mitsch, 2000) and is assumed to be proportional to net primary productivity (NPP flow) of the wetland macrophyte. Loss of phosphorus in biomass to detritus, and then to the sediment through decomposition processes was generally simulated as a linear pathway. Calibration efforts were generally focused on percent phosphorus removal prediction in constructed wetlands.

\section{Economic Accounting Submodel}

Two different aspects of potential cost saving from recycling FGD wastes as liners in constructed wetlands were explored in this submodel. One was a cost saving from wetland construction with FGD liners relative to commonly used clay materials, which provide useful a priori information to managers and decision-makers on treatment wetlands. The cost of wetland construction varies widely, depending on the location, type, size, and objectives of the 
(a).

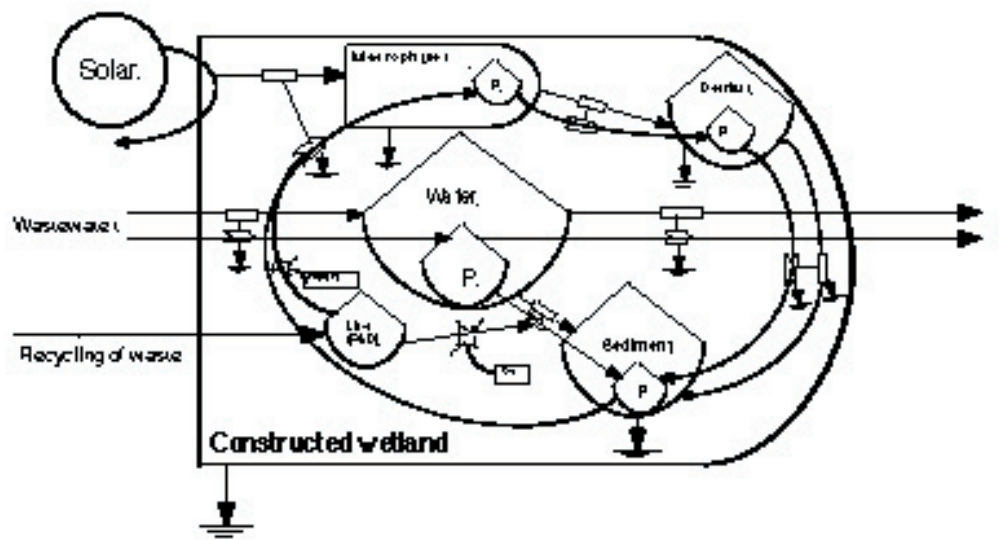

(b)

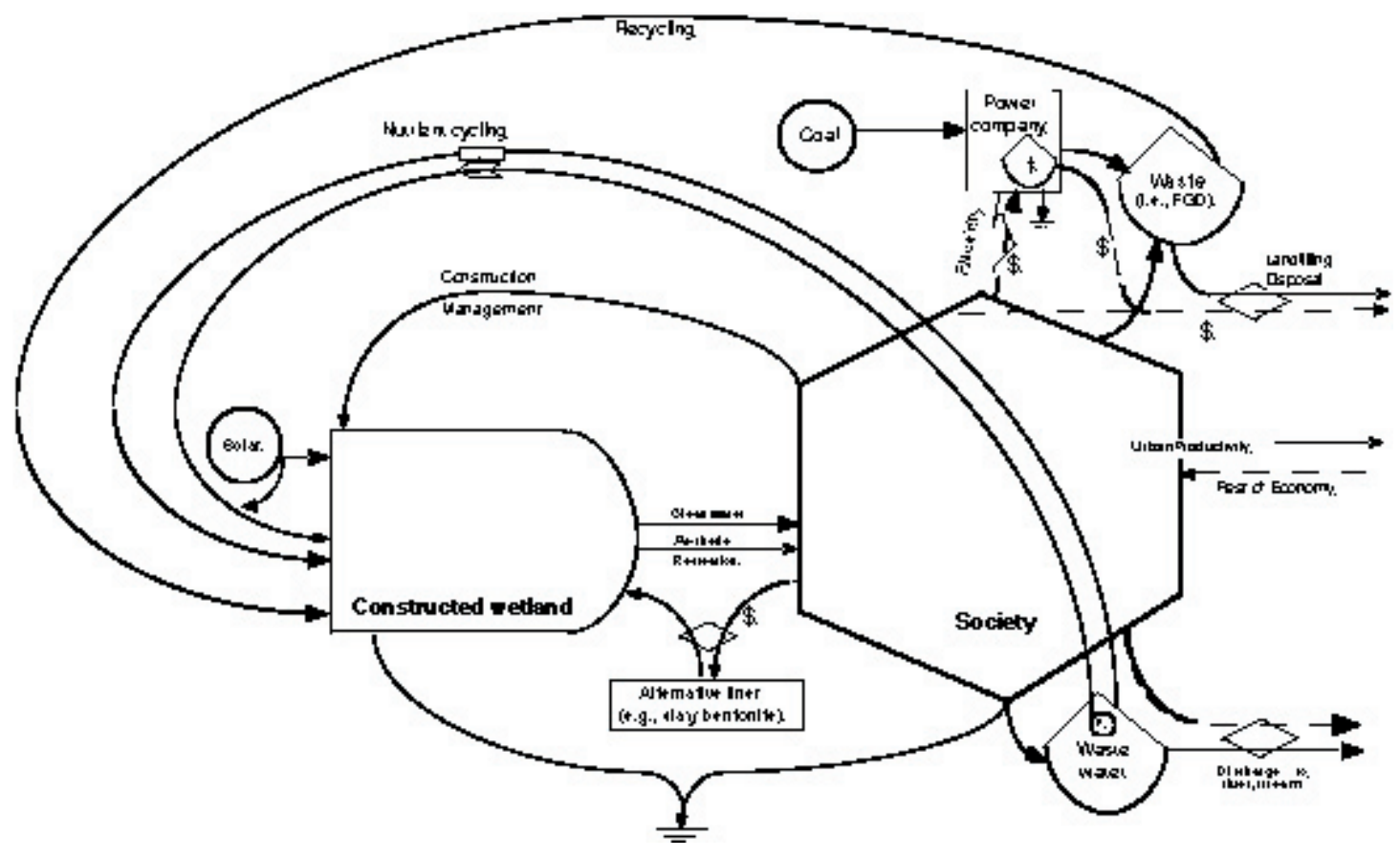

Figure 1. Conceptual model of ecological-economic system of a constructed wetland with recycled coal combustion wastes; (a) Detail phosphorus processes in a constructed wetland including FGD liner; (b) Connection between a constructed wetland shown in (a) with economics and society. 
Table 1. Differential equations used in the ecologic-economic wetland model.

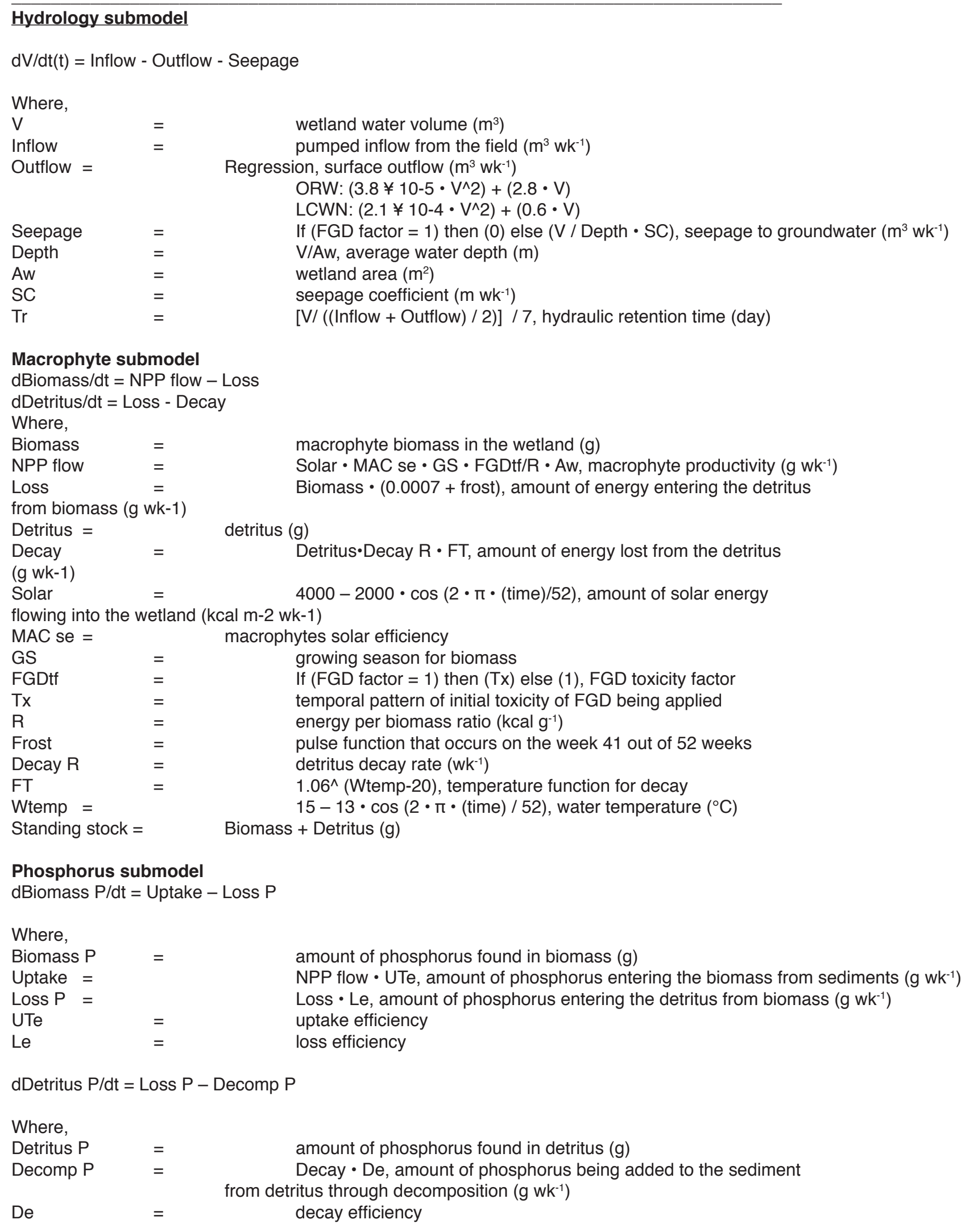


$\mathrm{dSediment} \mathrm{P} / \mathrm{dt}=$ Decompo P $+\mathrm{ST}-$ Uptake

Where,

Sediment $\mathrm{P} \quad=\quad$ amount of phosphorus found in the sediment $(\mathrm{g})$

ST $\quad=\quad$ If $($ standing stock $<4 ¥ 106)$ then $($ Water $\mathrm{P} \cdot \mathrm{STC} /$ depth) else

((standing stock $• 5 ¥ 10-8+$ STC)/depth $•$ Water P), amount of phosphorus entering the sediment from water (g $\left.\mathrm{wk}^{-1}\right)$

Sed $\mathrm{k} \quad=\quad$ phosphorus sedimentation velocity $(\mathrm{m} w \mathrm{w}-1)$

$\mathrm{dWater} \mathrm{P} / \mathrm{dt}=$ Inload - Outload $-\mathrm{ST}-\mathrm{P}$ seepage - FGD effect

Where,

Water $\mathrm{P}=\quad$ amount of phosphorus found in the water $(\mathrm{g})$

Inload $=$ Inflow $\cdot$ Inconc, amount of phosphorus entering the water column

$\left(\mathrm{g} \mathrm{wk}^{-1}\right)$

Outload $=\quad$ Water $\mathrm{P} \cdot$ Outflow $/ \mathrm{V}\left(\mathrm{g} \mathrm{wk}^{-1}\right)$

$P$ seepage $=$ If $(F G D$ factor $=1)$ then $(0)$ else (seepage $\cdot($ Inconc + Outconc)/2),

phosphorus loss from water column through seepage ( $g$ wk-1)

FGD effect = If (FGD factor $=1$ ) then (Water $P \cdot F G D$ CaP) else $(0)$, additional

phosphorus retention by FGD $\left(\mathrm{g} \mathrm{wk}^{-1}\right)$

Inconc $=$ total phosphorus concentration of inflow from the field $\left(\mathrm{g} \mathrm{m}^{-3}\right)$

Outconc $=$ Water $P / \mathrm{N}$, total phosphorus concentration of outflow $\left(\mathrm{g} \mathrm{m}^{-3}\right)$

$\mathrm{FGD} \mathrm{CaP}=\mathrm{Ca}-\mathrm{P}$ precipitation efficiency

P removal conc $=($ In conc - Out conc $) /$ In conc $\cdot 100$, Percent removal of

phosphorus based on concentration (\%)

$\mathrm{P}$ removal load $=($ Inload - Outload $) /$ Inload $\bullet 100$, Percent removal of phosphorus

based on load (\%)

$\mathrm{P}$ removed with clay $=($ Inload - Outload $)$, amount of phosphorus removed with clay liner

$\left(\mathrm{g} \mathrm{wk}^{-1}\right)$

$P$ removed with $F G D=($ Inload - Outload $) \cdot 1.1$, amount of phosphorus with FGD liner $\left(\mathrm{g} \mathrm{wk}^{-1}\right), 10 \%$ additional $P$ retention assumed (e.g., Ahn et al., 2000)

\section{Economic accounting submodel}

Liner cost saving = -PMT (Interest rate, NY, Liner saving, 0), annualized payment on the capital cost of a constructed wetland with FGD wastes $\left(\$ \mathrm{yr}^{-1}\right)$; PMT function returns a negative value, indicating that the payment is an expense, so (-) is applied to the PMT to produce (+) value of the saving from the recycling of FGD wastes as liners.

Cost for wetland $=196336 \cdot(\mathrm{Wt} \text { area })^{\wedge}(-0.511) \cdot(\mathrm{Wt}$ area $)$, regression equation for calculating the cost of wetland construction from Mitsch and Gosselink (2000) (\$)

$\mathrm{P}$ treatment saving $=(\mathrm{P}$ removed with $\mathrm{FGD}-\mathrm{P}$ removed with clay $) \cdot$ Unit cost of $\mathrm{P}$

wetland $\cdot 52 \cdot 2$, amount of money saved by the enhanced removal of

phosphorus due to FGD by-products $\left(\$ \mathrm{yr}^{-1}\right)$

Interest rate $=\quad 0.08$, annual interest assumed $(8 \%)$

NY $=30$, lifetime of constructed wetland assumed (years)

Total savings $=$ Annualized cost saving + FGD treat saving $(\$ y r-1)$

Liner cost $=$ Cost for wetland construction $\cdot 0.2$, approximately $20 \%$ of the

construction cost is for liner (\$)

Unit cost of $\mathrm{P}$ wetland $=0.1781 \cdot \ln \operatorname{conc}^{\wedge}(-0.7151)$, regression equation developed on unit cost of phosphorus removal in constructed wetlands $\left(\$ g-\mathrm{P}^{-1}\right)$

Wt area $=$ total area of wetland constructed (6.4 for LCW) (ha) 

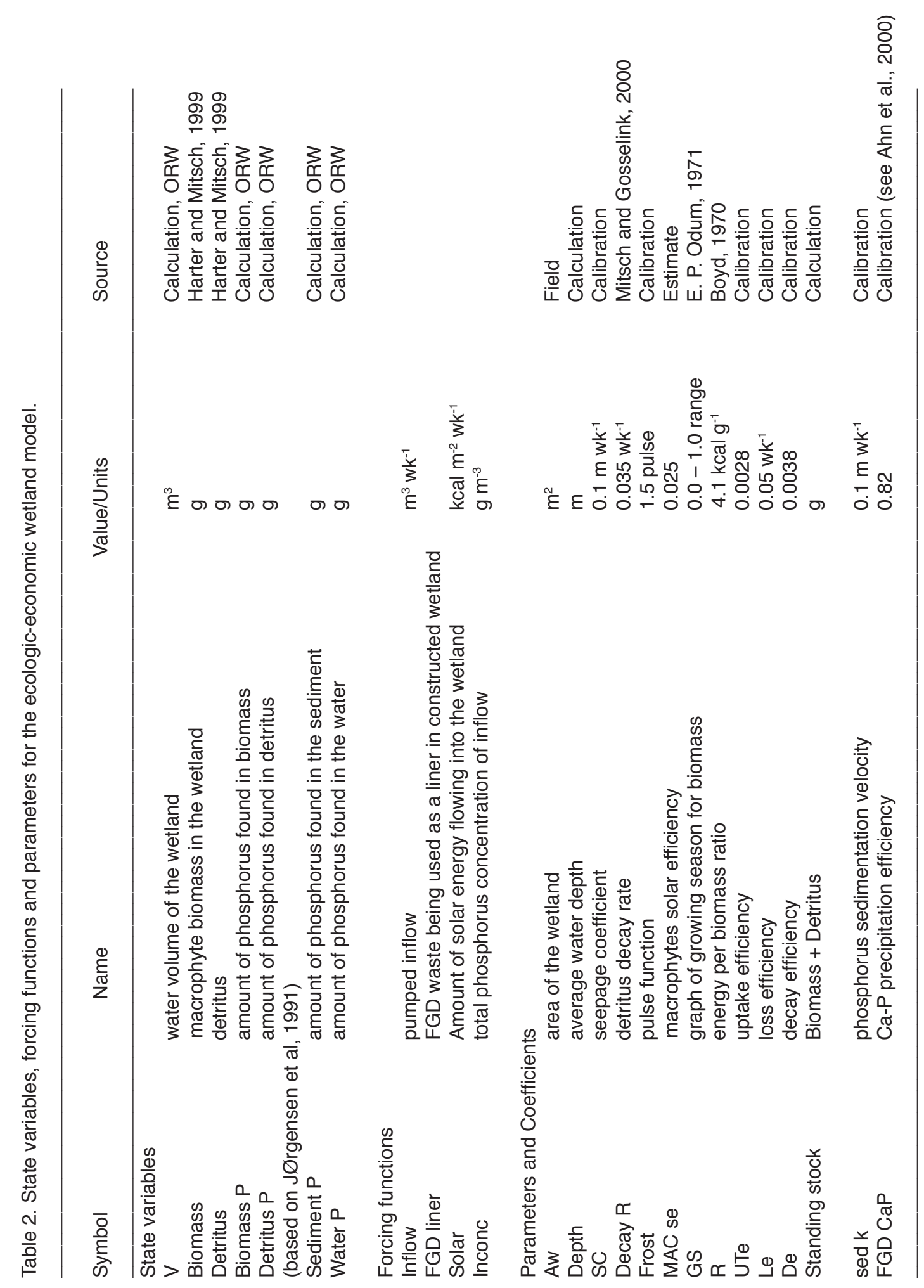
wetland (Mitsch and Gosselink, 2000). A strong relationship between wetland cost per area and wetland size found by Mitsch and Gosselink (2000) based on various cases of treatment wetlands in the US, including the ORW and the LCW, was used in our economic accounting submodel to calculate cost of wetland construction.

$\mathrm{CA}=\$ 196,336 \cdot \mathrm{A}^{-0.511} \mathrm{n}=15 \mathrm{R}^{2}=0.785$

where,

$\mathrm{CA}=$ capital cost of wetland construction per unit area,

$$
A=\text { wetland area, ha }
$$

Cost of liner material is generally reported to comprise $20-25 \%$ of total wetland construction cost (Kadlec et al., 2000). In the model, we applied $20 \%$ of the total estimated cost of wetland construction conservatively as the potential saving of using FGD waste relative to clay being purchased. The capital saving of FGD liner was converted into an annualized saving based on an assumed 8\% interest rate and 30-year lifetime of a constructed wetland.

The other possible saving from using FGD waste as a liner results from cost of phosphorus removal in constructed wetlands. Bystrom (1998) estimated nitrogen removal cost in wetlands by linking a function for construction costs of wetlands with a function that defines the nitrogen removal capacity of wetlands. Similarly, in our study, a possible cost saving $\left(\$\right.$ year $\left.^{-1}\right)$ was calculated by multiplying the unit cost of removing one gram of total phosphorus from surface inflow by the amount of phosphorus being additionally removed due to FGD by-product compared to clay (see Table 1).

The unit cost of phosphorus removal would be a useful tool in the development plans for a reliable, implementable treatment system at a reasonable cost. Very few studies have been conducted on how much it would cost to treat a unit mass of phosphorus through wetland treatment technology. In order to quantify the removal cost of a unit mass of phosphorus in our study, we used data available from real-world examples including North American Wetland Database (NAWDB, 1993), ORW and LCW to obtain construction costs of those wetlands. Those capital construction costs were converted into periodic series of annualized payments for a 30 year period at an $8 \%$ interest rate, and then added it to annual operation and maintenance costs of those wetlands to calculate the total annual costs. The calculated total annual costs were adjusted to January 2000 by multiplying by 1.176 based on Mean history cost index (Means Company Inc., 1999) as most construction costs adopted in the calculations were in 1993 dollars. The total annualized cost for each constructed wetland calculated was then divided by total annual amount of phosphorus removed through it, thus resulting in unit cost (\$) of one gram of phosphorus removed. Values of all other possible services being provided by constructed wetlands such as recreation, biodiversity and removal of other nutrients or pollutants, although important, are not included in this unit cost estimation. Amount of phosphorus entering the water column (Inload, kg-P ha-1 day-1) and total phosphorus concentration of inflow (Inconc, $\mathrm{g} \mathrm{m}$-3) were found to be closely related to unit cost of phosphorus removed in constructed wetlands in a previous study (Brown and Caldwell Consultants, 1993). Therefore, we established two power functions to describe the relationship between unit cost and phosphorus loading in constructed wetlands:

Unit cost $=0.0673 \cdot \operatorname{Inload}^{(-0.8189)}$

$\mathrm{n}=5 \quad \mathrm{R}^{2}=0.5375$

Unit cost $=0.1781 \bullet$ Inconc $^{(-0.7151)}$

$\mathrm{n}=5 \quad \mathrm{R}^{2}=0.9753$

where,

Unit cost $=$ cost of removing one gram of total phosphorus, US $\$ \mathrm{~g}-\mathrm{P}^{-1}$

Inload $=$ amount of phosphorus entering the water column, $\quad \mathrm{kg}-\mathrm{P} \mathrm{ha}^{-1}$ day $^{-1}$

Inconc $=$ total phosphorus concentration of inflow, $\mathrm{g} \mathrm{m}^{-3}$

In the above equations, the unit cost of phosphorus removed decreases drastically as TP inflow concentration increases as found in Brown and Caldwell Consultants (1993). Inflow TP concentration explained almost $98 \%$ of the variance of unit cost of removing one gram of TP through constructed wetlands. Therefore, the second equation was adopted in our model to link the phosphorus submodel to the economic accounting submodel.

\section{Results and Discussion}

The model was used to simulate ecologic-economic dynamics of phosphorus retention in constructed wetlands. Table 4 summarizes simulations performed in this study.

\section{Simulation Results - Calibration and Validation}

The process of calibration consists of adjusting key model parameters so that simulated values for a modeled variable (TPoutflow concentration or \% TPremoval) are in agreement with observed field data. The hydrology submodel was the first submodel to be calibrated, and showed less than $10 \%$ difference for average surface outflow at each time step (m3 wk-1) between field data and model outputs. Water depth was predicted almost the same as their field measurements for two different sites (ORW 1:0.2 m; LCWN: $0.25 \mathrm{~m}$ ), resulting in less than $5 \%$ difference.

Model performance in predicting phosphorus retention is presented in Figure 2. Percent phosphorus removal is used as a criterion for evaluating the model's performance. The calibrated model predicted $0.092 \mathrm{~g}-\mathrm{P} \mathrm{m}-3$ for TP outflow concentration, thus achieving $43.2 \% \mathrm{TPremoval}$ on average over a 2-year period through the ORW 1. Calibrated percent TPremoval was in good agreement with the actual percent TP removal of the ORW 1 (38.9\% on average), showing about $10 \%$ error from the actual retention. The LCWN used for validation showed a $20 \%$ difference between field-measured and simulated phosphorus retention but this margin of error is quite acceptable in this type of general prediction over 


\section{a 2-year period.}

Figure 3 shows phosphorus dynamics simulated for the four main state variables such as biomass, detritus, sediment and water column in the LCWN. This simulation describes plant-soil-water interactions fairly well in the wetland ecosystem. Phosphorus in the water (Water P) fluctuated between $0 \mathrm{~g}-\mathrm{P} \mathrm{m}^{-2}$ and $1.27 \mathrm{~g}-\mathrm{P} \mathrm{m}^{-2}$ with an average value of $0.22 \mathrm{~g}-\mathrm{P} \mathrm{m}^{-2}$ over a 2-year period. Water P remained low during the growing season and showed relatively higher peaks as the growing season ended.

Biomass production and standing stock start as the growing season begins, which both influence sedimentation of phosphorus positively. Therefore, phosphorus in the water column is closely affected by the macrophyte submodel, and hence shows a kind of seasonality. Phosphorus in plant biomass fluctuates between about $0.03 \mathrm{~g}-\mathrm{P} \mathrm{m}^{-2}$ and $2.03 \mathrm{~g}-\mathrm{P} \mathrm{m}^{-2}$ in the LCW simulation seasonally because of its dependence on the macrophyte submodel. As NPP flow increases, uptake of phosphorus from the sediment also increases (Figure 3). The outflow pathway of biomass phosphorus is directly dependent on the loss rate of biomass to detritus in the macrophyte submodel (Table 1). Biomass $\mathrm{P}$ is also affected greatly by the occurrence of frost which terminated the growing season in week 41 of the first year and in week 93 of the second year. The phosphorus in detritus (Detritus P) follows an inverse pattern of the phosphorus in biomass. As biomass $\mathrm{P}$ decreases on week 41, the phosphorus flows from biomass to detritus. Phosphorus in the sediment (Sediment $\mathrm{P}$ ) increases over time and reaches a peak of $76 \mathrm{~g}-\mathrm{P} \mathrm{m}-2$ over a 2 -year period in the LCW, but it shows a relatively lower rate of increase during the growing seasons compared to non-growing seasons since macrophyte uptake of phosphorus from sediments drastically increases (Figure 3).

\section{Sensitivity Analysis}

Figure 4 shows how percent TP removal of wetlands changes as phosphorus sedimentation coefficient (sed k) changes. TP retention in wetlands increases as sed k increases, thus indicating that phosphorus sedimentation is a significant process contributing to phosphorus retention efficiency of our wetland model. Inflow TP concentration was also varied from the inflow TP concentration of the LCWN by \pm 2 orders of magnitude, which did not significantly influence percent TP removal in the wetland model when the inflow TP concentration was higher than $0.12 \mathrm{~g} \mathrm{~m}^{-3}$ as shown in Figure 5. Inflow TP concentration of $0.12 \mathrm{~g} \mathrm{~m}^{-3}$ is usually regarded a low-Pcondition as in the river inflow of the ORW (Spieles and Mitsch, 2000). Most treatment wetlands are found to have higher inflow TP concentrations than 0.12 $\mathrm{g} \mathrm{m}^{-3}$ (Kadlec and Knight, 1996). Therefore, TP retention predicted in our model may not be sensitive to change in the inflow TPconcentrations of treatment wetlands. Rapidly decreasing percent TP removal was observed when Inflow TP concentration was below $0.2 \mathrm{~g} \mathrm{~m}^{-3}$ (Figure 5).

\section{Simulations for the Pilot-Scale Wetland with a FGD Liner}

We ran the dynamic model with a variety of combinations of hydraulic loading rates and inflow TP concentrations for the pilot-scale wetland $(\approx 3 \mathrm{~m} \times 7.8 \mathrm{~m} \times 1.5 \mathrm{~m})$ lined with FGD by-product currently under construction at the ORWRP. Table 5 shows those simulation results. Mitsch and Gosselink (2000) reported that loading rates to surface flow wetlands for wastewater treatment from small municipalities ranged from 1.4 to $22 \mathrm{~cm}$ day-1 (average $=5.4 \mathrm{~cm} \mathrm{day}^{-1}$ ). Knight (1990) recommended a rate of 2.5 to $5 \mathrm{~cm} \mathrm{day}^{-1}$ for surface water systems. The rate of $5-10 \mathrm{~cm} \mathrm{day}^{-1}$ was also maintained for the ORW and LCW since they were constructed (Spieles and Mitsch, 2000). Therefore, we chose $5 \mathrm{~cm} \mathrm{day}^{-1}$ as target inflow loading rate, one of the design parameters for this pilot-scale wetland, and ran the model while varying the value within a reasonable range from 2.5 to $15 \mathrm{~cm} \mathrm{day}^{-1}$. Inflow TP concentration was also varied from 0.1 to $10 \mathrm{~g}$ $\mathrm{m}^{-3}$, a reasonable value range for treated wastewater entering constructed wetlands based on the NAWDB (1993), while fixing the hydraulic loading rate at $5 \mathrm{~cm} \mathrm{day}^{-1}$ to investigate the change in phosphorus retention. As hydraulic loading rates increased from 2.5 to $15 \mathrm{~cm}^{\text {day }}{ }^{-1}$ percent $P$ removal (on average as mass) decreased by $29 \%$ when the inflow TP concentration was consistently kept at $2 \mathrm{~g} \mathrm{~m}^{-3}$ as shown in Table 5. The model estimated more than $60 \%$ phosphorus removal consistently when inflow TP concentration varied from 0.1 to $10 \mathrm{~g} \mathrm{~m}^{-3}$ at $5 \mathrm{~cm} \mathrm{day}^{-1}$ of hydraulic loading rate (Table 5). Most simulations predicted more than 50\% TP retention except the case where the hydraulic loading rate was $15 \mathrm{~cm}^{-1 a y^{-1}}$ and inflow TP concentration was $2 \mathrm{~g}$ $\mathrm{m}^{-3}$. Mean TP retention over a 2-year run of the model in this case was less than $45 \%$, thus indicating the hydraulic loading rate is the major determinant of phosphorus retention performance predicted by the model.

Retention time in Table 5 was calculated by the simple theoretical equation below (Mitsch and Gosselink, 2000).

$$
\mathrm{t}=\mathrm{Vp} / \mathrm{Q}
$$

where,

$\mathrm{t}=$ theoretical retention time (day)

$\mathrm{V}=$ volume of water for surface flow wetland $\left(\mathrm{m}^{3}\right)$

$\mathrm{P}=$ porosity of medium, $\sim 1.0$ for surface flow wetlands

$\mathrm{Q}=$ flow rate through wetland $\left(\mathrm{m}^{3}\right.$ day $\left.^{-1}\right)$

$=(\mathrm{Qi}+\mathrm{Qo}) / 2$, where Qi is inflow and Qo is outflow

Manipulating water depth can change calculated retention time. The pilot-scale FGD-lined wetlands are designed to control water depth so that we can change the retention time of water being treated in the wetlands. The values in parentheses in Table 5 for water depth and retention time show those possible changes. Based on those simulations explored we suggested design parameters for the pilot-scale experimental wetlands (Table 6). We chose $5 \mathrm{~cm}$ day- 1 as a conservative loading rate and 2-3 g m-3 typical of treated 
Table 3. Hydrology, phosphorus loading data (mean \pm S. E., $(n))$ for the Olentangy River Wetland (ORW) and the Licking County Wetland (LCW), 1996-1997.

\begin{tabular}{lll}
\hline Parameters & ORW basin 1 & LCW north basin \\
\hline Area (ha) & 1 & 3.2 \\
Inflow $\left(\mathrm{m}^{3}\right.$ day $\left.^{-1}\right)$ & $932 \pm 40(75)$ & $3,138 \pm 127(87)$ \\
Hydraulic loading rate $(\mathrm{cm} / \mathrm{d})$ & $9.3 \pm 0.4(75)$ & $9.8 \pm 0.40(87)$ \\
Retention time $(\mathrm{d})$ & $2.1 \pm 0.3(75)$ & $2.6 \pm 0.2(87)$ \\
Inflow P concentration $\left(\mathrm{mg} \mathrm{P} \mathrm{L}^{-1}\right)$ & $0.16 \pm 0.01(75)$ & $1.19 \pm 0.15(87)$ \\
P removal by concentration $(\%)$ & $38.9 \pm 1.1(75)$ & $20 \pm 1.2(87)$
\end{tabular}

Table 4. Simulations run of the ecologic-economic wetland model in this study.

\begin{tabular}{ll}
\hline Simulation Number of simulations & Numben
\end{tabular}

Calibrating model of ecosystem (phosphorus)

1. Calibration of model with the ORW a 1 data in 1996-1997

2. Validation of model with the LCW b data in 1996-1997

Sensitivity analysis (with LCW)

3. Phosphorus sedimentation coefficient (sed k) 5

4. Interest rate and wetland life expectancy 4

5. Total phosphorus inflow concentration $\quad 5$

Simulations to design a pilot-scale wetland lined with FGD

6. Manipulating hydraulic loading rate and inflow TP concentration (7 different $\mathrm{P}$ loading rate simulated)

Real-world application of the model with LCW

7. LCW with clay liner (no seepage)

1

8. LCW with FGD liner (no seepage + FGD effects)

1

a Olentangy River Wetland; the data from ORW basin 1 was used.

${ }^{b}$ Licking County Wetland; the data from the north basin (LCWN) was used. 


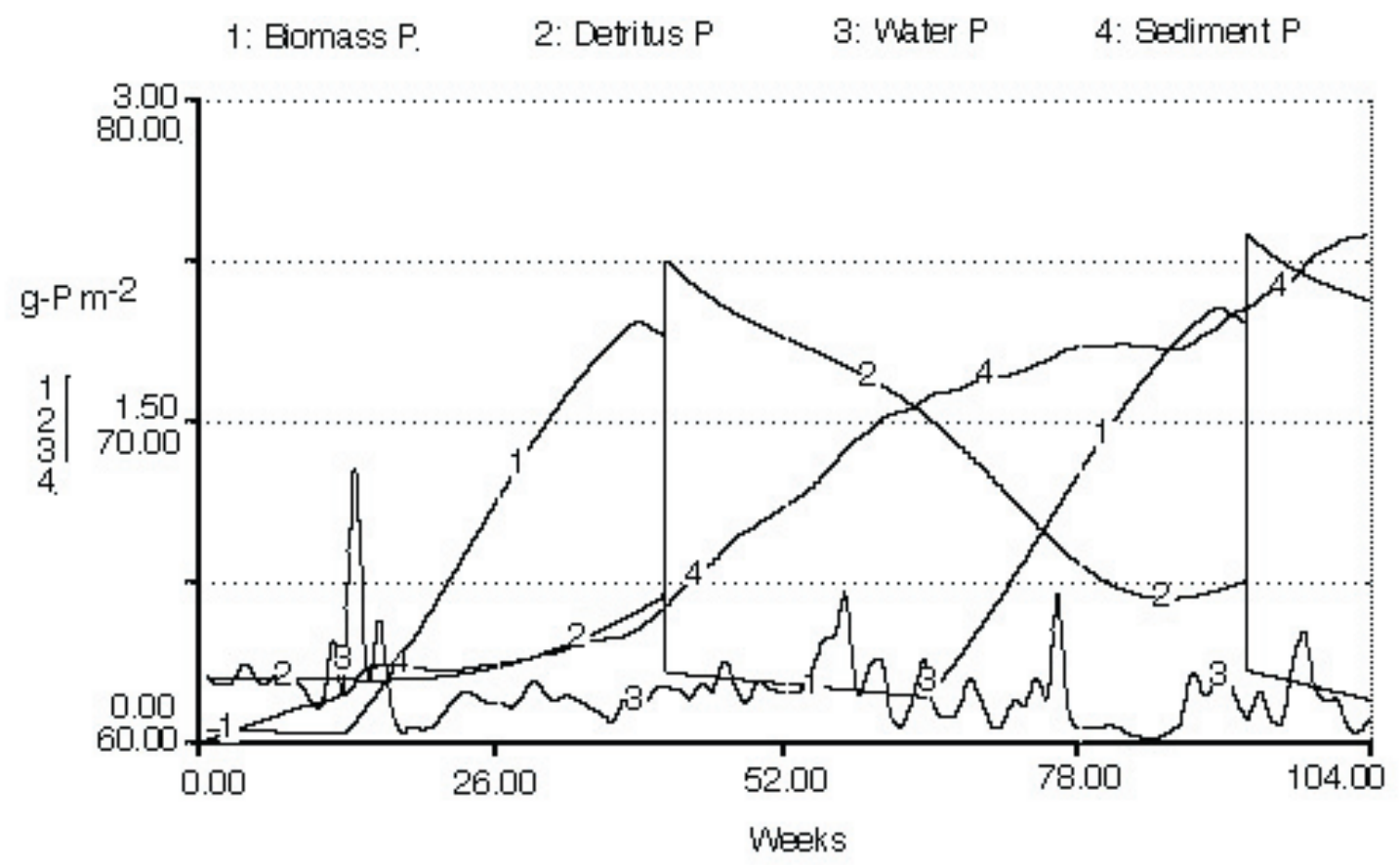

Figure 3. Simulation phosphorus dynamics in biomass, detritus, water and sediment in LCW over a 2-year period (1996-1997) in this study.

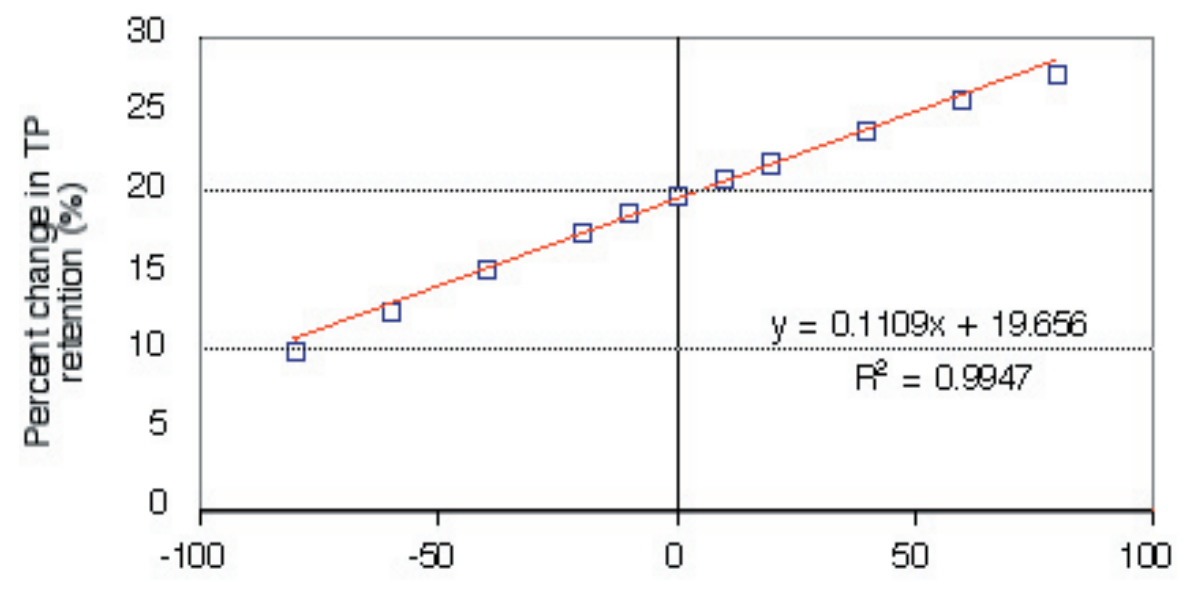

$\%$ change in sed $k$.

Figure 4. Sensitivity of percent change in total phosphorus retension to phosphorus sedimentation coefficient (sed k). 

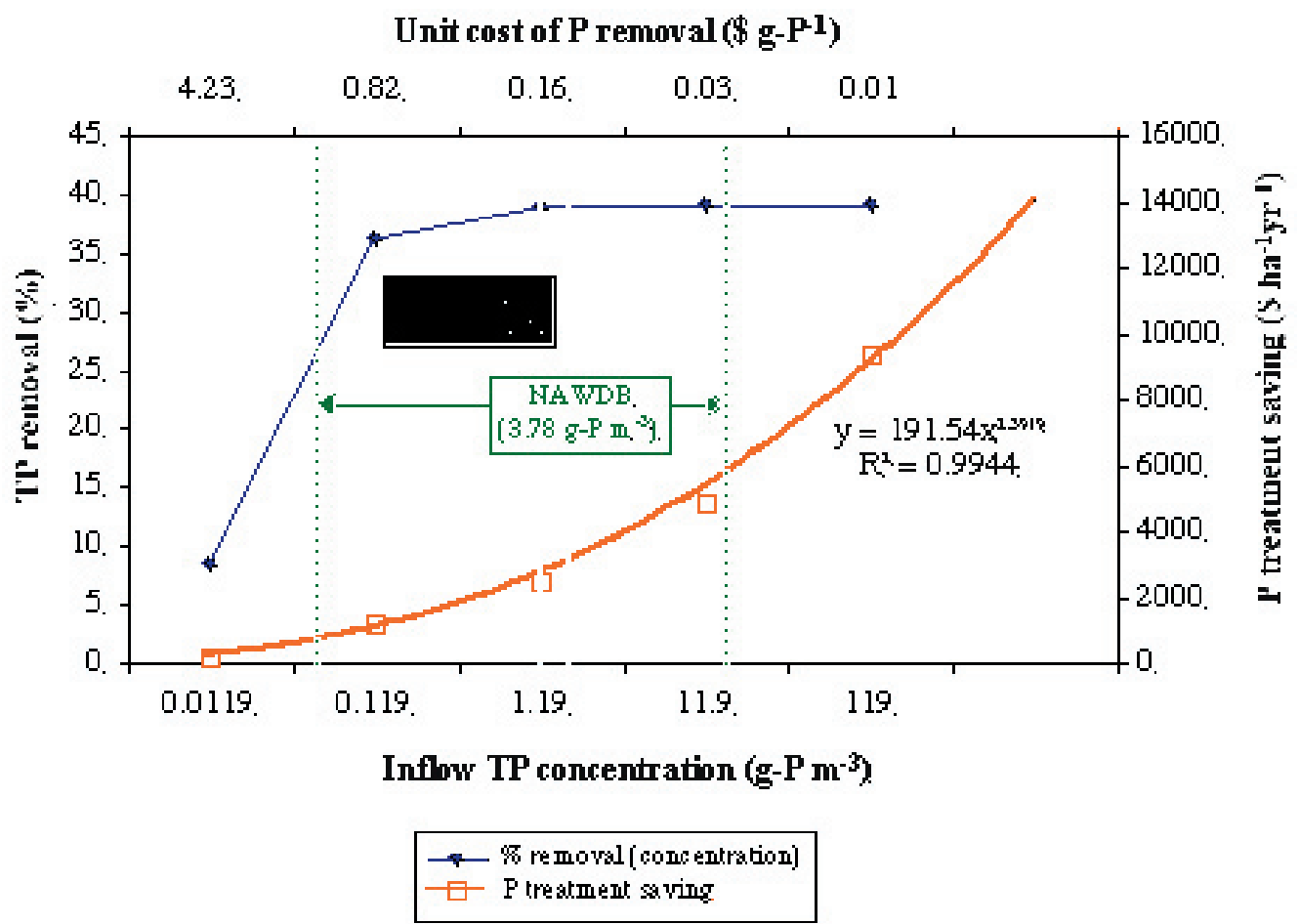

Figure 5. Relationship of TP removal (\%), Unit cost of $\mathrm{P}$ removal, and $\mathrm{P}$ treatment savings along a gradient of inflow TP concentration in the calibrated model simulating LCW in this study. Two thick, vertically-dotted lines indicates minimum and maximum values of inflow TP from North American Treatment Wetland Database (NAWDB, 1993). LCWN is licking County Wetland North basin. Values in the boxes are mean inflow TP concentrations for LCWN and NAWDB.

Table 5. Simulations conducted over a 2-year period under various combinations of hydraulic and phosphorus loading rates to design the pilot-scale wetland $(\approx 3 \mathrm{~m} \times 7.8 \mathrm{~m} \times 1.5 \mathrm{~m})$ lined with FGD by-product in this study.

\begin{tabular}{lllllll}
\hline Simulation & $\begin{array}{l}\text { Hydraulic } \\
\text { loading } \\
\left(\mathrm{cm} \mathrm{day}^{-1}\right)\end{array}$ & $\begin{array}{l}\text { Water } \\
\text { depth a } \\
(\mathrm{m})\end{array}$ & $\begin{array}{l}\text { Retention } \\
\text { time a } \\
\text { (day) }\end{array}$ & $\begin{array}{l}\text { Inflow } \mathrm{P} \\
\text { concentration } \\
\left(\mathrm{g} \mathrm{m}^{-3}\right)\end{array}$ & $\begin{array}{l}\mathrm{P} \\
\text { loading } \\
\left(\mathrm{g} \mathrm{m}^{-2} \text { day }\right.\end{array}$ & $\begin{array}{l}\text { P removal }) \\
\text { (mass) } \\
(\%)\end{array}$ \\
\hline 1 & 2.5 & $0.06(0.12)$ & $2.5(5)$ & 2 & 0.05 & 74 \\
2 & 5 & 0.12 & 2.5 & 0.1 & 0.005 & 63 \\
3 & 5 & 0.12 & 2.5 & 2 & 0.1 & 63 \\
4 & 5 & 0.12 & 2.5 & 3 & 0.15 & 63 \\
5 & 5 & 0.12 & 2.5 & 10 & 0.5 & 63 \\
6 & 10 & $0.25(0.12)$ & $2.5(1.3)$ & 2 & 0.2 & 51 \\
7 & 15 & $0.37(0.12)$ & $2.5(0.83)$ & 2 & 0.3 & 45
\end{tabular}

\footnotetext{
a Values in parentheses show corresponding change between water depth and retention time.
} 
Table 6. Design parameters suggested for the pilot-scale FGD wetlands $(\approx 3 \mathrm{~m} \times 7.8 \mathrm{~m} \times 1.5 \mathrm{~m})$ at the Olentangy River Wetland Research Park (ORWRP).

\begin{tabular}{lc}
\hline Parameters & Suggested Design \\
\hline Type of flow & Surface flow \\
Hydrology & $5 \mathrm{~cm} \mathrm{day}^{-1}$ (for $>50 \% \mathrm{TP}$ removal) \\
Loading & $>1$ day $^{2}$ \\
Retention time & $0.1-0.3 \mathrm{~m}$ \\
Water depth & $2-3 \mathrm{~g} \mathrm{~m}^{-3}$ \\
Phosphorus loading & \\
Basin characteristics & Multiple (4) \\
Cells (number) & Scirpus sp. \\
Planting material & On-site soil over FGD by-product \\
Substrate material &
\end{tabular}

Table 7. Mean water depth and phosphorus retention of the Licking County Wetland (LCW) with two different types of potential liner, clay and FGD by-product, over a 2-year period of model simulation.

\begin{tabular}{llll}
\hline Simulation & $\begin{array}{l}\text { Water } \\
\text { depth } \\
(\mathrm{m})\end{array}$ & $\begin{array}{l}\text { P removal } \\
(\text { concentration) } \\
(\%)\end{array}$ & $\begin{array}{c}\text { P removal } \\
\text { (mass) } \\
(\%)\end{array}$ \\
\hline No liner a & 0.25 & 24.8 & 34.7 \\
Clay liner & 0.27 & 23.2 & 21.9 \\
FGD liner & 0.27 & 32.9 & 37. \\
\hline
\end{tabular}

a The case of validation

Table 8. Potential liner cost saving by recycling FGD by-product relative to clay as a liner in the Licking County Wetland (LCW) under various combinations of interest rate and life expectancy.

\begin{tabular}{lcc}
\hline $\begin{array}{l}\text { Life of wetland } \\
\text { (year) }\end{array}$ & $\begin{array}{l}\text { Interest rate } \\
(\%)\end{array}$ & $\begin{array}{l}\text { Liner cost saving } \\
\left(\text { US } \$ \text { ha }^{-1} \mathrm{yr}^{-1}\right)\end{array}$ \\
\hline 30 & 8 & $1,351(0 \%)$ \\
30 & 6 & $1,105(-18.2 \%)$ \\
30 & 10 & $1,613(+16.3 \%)$ \\
20 & 8 & $1,549(+12.8 \%)$ \\
40 & 8 & $1,275(-5.6 \%)$ \\
\hline
\end{tabular}

Table 9. Potential total cost saving of recycling FGD as a liner in the Licking County Wetland (LCW; $6.4 \mathrm{ha}$ ) predicted by the simulation model over a 2-year run in this study.

\begin{tabular}{llr}
\hline $\begin{array}{l}\text { Liner cost saving a } \\
\left(\mathrm{US} \$ \mathrm{yr}^{-1}\right)\end{array}$ & $\begin{array}{l}\text { P treatment saving } \\
\left(\mathrm{US} \$ \mathrm{yr}^{-1}\right)\end{array}$ & $\begin{array}{l}\text { Total cost saving } \\
\left(\mathrm{US} \$ \mathrm{yr}^{-1}\right)\end{array}$ \\
\hline 8,646 & 14,086 & 22,732 \\
\hline
\end{tabular}


wastewater as inflow TP concentration. Water depth is designed up to $0.3 \mathrm{~m}$ in the pilot-scale wetland (Table 6), high enough to contain other aquatic life than just macrophytes, e.g. amphibians and benthic invertebrates.

\section{Simulation of LCW with a Liner}

Table 7 shows the model simulations of LCWN with two different types of liners, either clay or FGD by-product. The same hydraulic loading rate $\left(9.8 \mathrm{~cm} \mathrm{day}^{-1}\right)$ and inflow TP concentration $\left(1.19 \mathrm{~g} \mathrm{~m}^{-3}\right)$ as in the model validation were applied to those simulations. The differences from the validation simulation was no seepage effect in both simulations of LCWN with an either clay or a FGD liner. Moreover, additional $\mathrm{P}$ retention and early phytotoxicity from FGD by-product were applied to the model simulation with a FGD liner. A slight increase of water depth was observed in the simulations with a liner due to no seepage (Table 7). The no seepage effect included in the model simulation with an either clay or FGD liner resulted in more phosphorus in the water column of the LCW, thus potentially decreasing phosphorus retention since no more phosphorus could be removed through seepage (see Table 1). Based on this model structure, the LCW with a clay liner showed a slight decrease in its phosphorus retention relative to that with no liner (Table 7). More investigation is needed on the physicochemical properties of the clay liner material being used for treatment wetlands. The pilot-scale wetlands lined with clay as a control to the FGD-lined ones may provide further information to be incorporated into the model as the experiment proceeds.

In the simulation of LCW with a FGD liner some changes of $\mathrm{P}$ dynamics were found compared to the simulation conducted without a FGD liner. Most importantly, biomass production was about $9 \%$ lower on average due to potential phytotoxicity applied in the model. This trend was much pronounced in the first year, showing about $14 \%$ lower biomass production as toxicity was modeled to mitigate over time and become negligible toward the end of the first year. Phosphorus in the biomass (Biomass P) was also 9\% lower than in the simulation with no liner. Reduction in biomass production naturally induced a decrease in detritus by an average of $12 \%$. As a result, standing stock, biomass plus detritus, showed a $10 \%$ decrease on average over a 2-year period, which may have influenced phosphorus retention performance of the wetland because the standing stock was modeled to influence phosphorus sedimentation. Higher percent TP removals both by concentration and by mass, however, were observed in the LCW simulated with a FGD liner compared to other simulations (Table 7). Amount of phosphorus in water column (Water P) showed a $10 \%$ additional decrease as a result of potentially enhanced $\mathrm{Ca}-\mathrm{P}$ precipitation included in the simulation. Therefore, model predictions show that increased phosphorus retention efficiency by FGD by-products offset the initial phytotoxicity that could otherwise negatively influence phosphorus retention.

\section{Economic Estimations}

Recycling FGD by-products in wetland treatment systems offers two possible cost savings; savings from both liner cost and phosphorus removal cost. Liner cost savings were estimated in the economic accounting submodel. This estimation presents only the cost of material for a liner, excluding cost for excavation and compaction procedures needed to install the liner. Based on the 30 -year, $8 \%$ interest assumption, calculation with the model resulted in the liner cost saving of about US \$ 1,400 ha ${ }^{-1} \mathrm{yr}^{-1}$ for the LCW (Table 8). A model equation calculating the cost of wetland construction is a function of wetland size, therefore the liner cost savings ( $20 \%$ of wetland construction cost assumed) will decrease proportionately to decreasing construction costs as the wetland being built gets bigger, following the so-called "economy of scale". Liner costs in general are variable, based on the quantity, thickness and type of material specified (Kadlec et al., 2000). The scenario tested above was based on the assumption that we would not find onsite soils with high clay content suitable for use as a liner. However, our approach remains reasonable and practical even at sites that do have high-clay soils. Kadlec and Knight (1996) reported that costs of testing and compaction, even with good soils in place, can exceed the costs of a $0.08-\mathrm{cm}$ polyvinyl chloride (PVC) liner.

Sensitivity of liner cost savings to the choice of interest rate and life expectancy of the wetland system was also explored (Table 8). If a $6 \%$ interest rate were chosen instead of $8 \%$, then the annualized cost savings of the liner would be $18.2 \%$ less or about US \$1,100 $\mathrm{ha}^{-1} \mathrm{yr}^{-1}$. If a $10 \%$ interest rate were applied, the cost savings would be $16.3 \%$ more or about US \$1,600 ha-1 $\mathrm{yr}^{-1}$. At a fixed 8\% rate, decreasing the life expectancy of the wetland from 30 years to 20 years resulted in about $13 \%$ increase in the annualized cost savings, while increasing it to 40 years decreased the cost savings by about $6 \%$. Therefore, it seems that the liner cost savings is sensitive to assumptions regarding interest rate and life expectancy of wetlands.

Figure 5 combines the other potential cost savings, $\mathrm{P}$ treatment savings, with both percent phosphorus removal predicted by the model and unit cost of $\mathrm{P}$ removal along a gradient of inflow TP concentrations. P treatment savings relates closely with inflow TP concentration $\left(r^{2}=0.9944\right)$ and increases as the TP concentration of surface inflow increases (Figure 5). P treatment savings can potentially get bigger than the liner cost savings with increasing TP inflow concentration, covering more than half of the total potential cost savings (Table 9). Two vertically-dotted lines in Figure 5 show the minimum and maximum values of inflow TP concentration observed for treatment wetlands in North America (NAWDB, 1993), showing how much savings can be possible in the LCW when the inflow TP concentration changes within that range. Table 9 presents total potential 
cost savings estimated from the FGD-lined LCW (6.4 ha), which was about US \$23,000 per year (US \$3,552 ha-1 $\mathrm{yr}^{-1}$ x 6.4 ha) by the model.

\section{Conclusion}

Recycling FGD by-products as liners in constructed wetlands may be environmentally beneficial and potentially economical. As long as we have to haul liner material to the site where the wetland treatment system is being constructed, FGD wastes provide an economic edge over clay or commercial liner materials. Enhanced phosphorus retention consistently applied in the model simulations through this study, however, needs more verification since it was based on the short-term, small-scale mesocosm studies. Therefore, recycling FGD wastes may or may not be as much economically feasible or cost-effective as projected in our study. A larger-scale, long-term wetland study with FGD wastes is currently underway to obtain more data, which may lead to better manifestation and applicability of our ecologic-economic model. Further studies of phosphorus dynamics in FGD-lined wetlands and full socio-economic assessment of recycling FGD wastes in treatment wetlands are still needed. The unique ecologic-economic modeling approach taken in this study is nonetheless valid and provides a bridge between wetland ecology and economic aspects of recycling FGD wastes in constructed wetlands.

\section{References}

Ahn, C. and W.J. Mitsch. 2001. Chemical analysis of soil and leachate from experimental wetland mesocosms lined with coal combustion products. J. Environ. Qual. 30: 1457-1463.

Ahn, C., W.J. Mitsch and W.E. Wolfe. 2001. Effects of recycled FGD liner on water quality and macrophytes of constructed wetlands: Amesocosm experiment. Wat. Res. 35: 633-642.

American Coal Ash Association Survey. 1997. 1996 Coal Combustion Product (CCP) Production and Use, American Coal Ash Association, Alexandria, VA.

Baker, K.A., M.S. Fennessy and W. J. Mitsch. 1991. Designing wetlands for controlling coal mine drainage: an ecologic-economic modelling approach. Ecol. Econ. 3: 1-24.

Boyd, C.E. 1970. Amino acid, protein, and caloric content of vascular aquatic macrophytes. Ecology 51: 902906.

Breaux, A., S. Farber and J. Day. 1995. Using natural coastal wetlands systems for wastewater treatment: An economic benefit analysis. J. Environ. Manag. 44: 285-291.

Brown and Caldwell Consultants. 1993. Everglades Protection Project, PHASE II Evaluation of Alternative
Treatment Technologies, Final Draft Report, Mock, Roos \& Associates, Inc.

Brown, L.C. and T. O. Barnwell Jr. 1987. The enhanced stream water quality models QUAL2E and QUAL2EUNCAS: documentation an user manual. EPA/600/387/007.

BystrÖm, O. 1998. The nitrogen abatement cost in wetlands. Ecol. Econ. 26: 321-331.

Cardoch, L., J.W. Day Jr, J.M. Rybczyk and G.P. Kemp. 2000. An economic analysis of using wetlands for treatment of shrimp processing wastewater - a case study in Dulac, LA. Ecol. Econ. 33: 93-101.

Flanagan, N.E., W.J. Mitsch and K. Beach. 1994. Predicting metal retention in a constructed mine drainage wetland. Ecol. Eng. 3: 135-159.

Grant, W.E. and P.B. Thompson. 1997. Integrated ecological models: simulation of socio-cultural constraints on ecological dynamics. Ecol. Mod. 100: 43-59.

Harter, S.K. and W.J. Mitsch. 1999. Patterns of short-term sedimentation in a freshwater created marsh. In: W.J. Mitsch and V. Bouchard (eds.), Olentangy RiverWetland Research Park at The Ohio State University, Annual Report 1998. The Ohio State University, Columbus, Ohio, pp. 95-112.

JØrgensen, S.E. 1988. Fundamentals of Ecological Modelling. Elsevier, Amsterdam.

JØrgensen, S.E., S.R. Nielsen and L.A. JØrgensen. 1991. Handbook of Ecological Parameters and Ecotoxicology, Elsevier, Amsterdam.

Kadlec, R.H. and D.E. Hammer. 1988. Modeling nutrient behavior in wetlands. Ecol. Mod. 40: 37-66.

Kadlec, R.H. and R. L. Knight. 1996. Treatment Wetlands. CRC Press, Boca Raton, FL.

Kadlec, R.H. 1997. An autobiotic wetland phosphorus model. Ecol. Eng. 8: 145-172.

Kadlec, R.H. and R.L. Knight, J. Vymazal, H. Brix, P. Cooper and R. Haberl. 2000. Constructed Wetlands for Pollution Control: Process, Performance, Design and Operation. IWA Publishing, London, England.

Knight, R.L. 1990. Wetland systems, in Natural Systems for Wastewater Treatment, Manual of Practice FD -16, Water Pollution Control Federation, Alexandria, Va., pp. 211-260.

Means Company Inc. 1999. Heavy Construction Cost Data: 2000, R. S. Means Company Inc., Kingston, MA.

Mitsch, W.J. and K. Metzker. 1996. Tertiary treatment of wastewater in southwest Licking County, Ohio, with a constructed wetland. Report to Southwest Licking County Community Water and Sewer District. The Ohio State University, Columbus, $\mathrm{OH}$.

Mitsch, W.J. and B.C. Reeder. 1991. Modeling nutrient retention of a freshwater coastal wetland: estimating the 
roles of primary productivity, sedimentation, resuspension and hydrology. Ecol. Mod. 54: 154-187.

Mitsch, W.J., X. Wu, R.W. Nairn, P.E. Weihe, N. Wang, R. Deal and R. Boucher. 1998. Creating and restoring wetlands: A whole ecosystem experiment in self-design. BioScience 48: 1019-1030.

Mitsch, W.J. and J.G. Gosselink. 2000. Wetlands 3rd Ed. Wiley, New York.

Nairn, R.W. and W.J. Mitsch. 2000. Phosphorus removal in created wetland ponds receiving river overflow. Ecol. Eng. 14: 107-126.

NAWDB. 1993. North American Treatment Wetland Database. Electronic database created by R. Knight, R. Ruble, R. Kadle and S. Reed for the United States Environmental Protection Agency. Copies available from Don Brown. USEPA Tel.: +1-513-569-7630.

Odum, E.P. 1971. Fundamentals of Ecology, Saunders, Philadelphia, PA.

Richardson, C.J. 1985. Mechanisms controlling phosphorus retention capacity in freshwater wetlands. Science 228: 1424-1427.

Richardson, C.J., S. Qian, C.B. Craft and R.G. Qualls. 1997. Predictive models for phosphorus retention in wetlands.
Wetl. Ecol. Manag. 4: 159-175.

Richmond, B. and S. Peterson. 1997. STELLA V: tutorials and technical documentation. High Performance Systems Inc., Hanover, New Hampshire.

Robles-Diaz-de-Leon, L.F. and A. Nava-Tudela. 1998. Playing with Asimina triloba (pawpaw): a species to consider when enhancing riparian forest buffer systems with non-timber products. Ecol. Mod. 112: 169-193.

Spieles, D.J. and W.J. Mitsch. 2000. The effects of season and hydrologic and chemical loading on nitrate retention in constructed wetlands: a comparison of low- and high nutrient riverine systems. Ecol. Eng. 14: 77 -91.

Wang, N. and W.J. Mitsch. 2000. Adetailed ecosystem model of phosphorus dynamics in created riparian wetlands. Ecol. Mod. 126: 101-130.

Wolfe, W.E., T.S. Butalia, W.J. Mitsch and E. Whitlatch. 2000. Use of Clean Coal Technology By-product in the Construction of Low Permeability Liners, Technical Report, Draft, Dept. of Civil and Environmental Engineering and Geodetic Science \& School of Natural Resources, The Ohio State University, Columbus, $\mathrm{OH}$. 